Religion and Gender, vol. 1, no. 1 (2011), 104-124

www.religionandgender.org

URN: NBN:NL:UI:10-1-101580

ISSN: 1878-5417

Publisher: Igitur Publishing (Utrecht)

Copyright: this work is licensed under a Creative

Commons Attribution License (3.0)

\title{
Male Headship as Male Agency: An Alternative Understanding of a 'Patriarchal' African Pentecostal Discourse on Masculinity
}

ADRIAAN S. VAN KLINKEN

\begin{abstract}
In some Christian circles in Africa, male headship is a defining notion of masculinity. The central question in this article is how discourses on masculinity that affirm male headship can be understood. A review of recent scholarship on masculinities and religion shows that male headship is often interpreted in terms of male dominance. However, a case study of sermons in a Zambian Pentecostal church shows that discourse on male headship can be far more complex and can even contribute to a transformation of masculinities. The main argument is that a monolithic concept of patriarchy hinders a nuanced analysis of the meaning and function of male headship in local contexts. The suggestion is that in some contexts male headship can be understood in terms of agency.
\end{abstract}

\section{Keywords}

Masculinity; agency; patriarchy; Pentecostalism; African Christianity

\section{Author affiliation}

Adriaan van Klinken received his PhD in Religious Studies from Utrecht University (2011) with a dissertation on transformations of masculinity in African Christianity in the context of the HIV epidemic. This Fall he will join the Centre for Gender and 
Religions Research in the School of Oriental and African Studies, University of London, as a postdoctoral research fellow. Email: home@adriaanvanklinken.net

\section{Introduction ${ }^{1}$}

'We men are the head, but you have to live up to it. We like to be the head, but we don't like to live up to the responsibility. That's our problem!'

Bishop Joshua H. K. Banda

Consider for a moment the above statement. Is it just an affirmation of the traditional view of men as heads of their households? Does it simply echo the long tradition of patriarchal discourse in Christianity? Or is the notion of male headship employed to induce behavioural change among men? Is it used to transform hegemonic forms of masculinity? Of course, the quotation is too short to answer these questions. One needs to know more about the context of the statement, both textually and socially. However, I think that at the very first sight the quotation - and the sermon from which it is taken - raises suspicion among many scholars trained in the critical study of religion and gender. After all, a 'feminist hermeneutics of suspicion' is one of the key tools, not only in biblical studies, where this concept was coined by Elizabeth Schüssler-Fiorenza, but also in the broader fields of feminist theology and gender-critical studies in religion. ${ }^{2}$ First generation feminist scholars, such as Mary Daly and Rosemary Radford Ruether, have voiced sharp criticism of the idea of male headship in Christianity. According to Daly, it has 'dehumanizing aspects' to women and 'paralyzes them by a degrading doctrine'. ${ }^{3}$ Likewise, Ruether considers

1 This article is a revised version of the paper 'Beyond the Patriarchy-Framework: Feminist Theory and the Study of Masculinities and Religion', presented at the annual meeting of the American Academy of Religion in Atlanta, 30 October 2010. The author thanks the organizers and participants of the session for their interest, questions and comments, and also thanks the reviewers and editors of this journal for their valuable feedback on an earlier version of this article.

2 A.-J. Leville, 'Hermeneutics of Suspicion' in L.M. Russell and J.S. Clarkson (eds.), Dictionary of Feminist Theology, Louisville: Westminster John Knox Press 1996, 140141; U. King, 'Introduction: Gender and the Study of Religions' in U. King (ed.), Religion and Gender, Malden: Blackwell 1995, 22.

3 M. Daly, The Church and the Second Sex (2 ed.), New York: Harper \& Row 1975, 167 and 188. 
it a symbol of patriarchal anthropology. ${ }^{4}$ She explores how concepts such as male headship have worked in shaping marriage and family life in Christian traditions up to date, and she stresses the theological need for 'a clear and explicit rejection of the doctrine that holds that the patriarchal family of male headship and female subordination is the "order of creation", mandated by God. ${ }^{5}$ These voices represent first generation feminist scholarship. Since then the study of religion and gender has moved on, developing less ideologically driven approaches. However, the suspicion of religious ideologies that promote male headship is still there.

This article is not intended as a general discussion on male headship in Christian contexts. I am not interested in the normative theological question whether or not Christianity teaches male headship. ${ }^{6}$ I simply observe that some churches do teach it, and my interest is in the meaning of their teachings in specific socio-cultural contexts. Therefore I will present a case study. The above quotation is from bishop Joshua Banda, a prominent Pentecostal leader in Zambia. In 2008, Banda delivered a series of sermons in his church, entitled Fatherhood in the $21^{\text {st }}$ Century. In these sermons an ideal of 'biblical manhood' is developed, and indeed the notion of male headship is central to this ideal. The sermons are an illustration of the emergence of 'new concepts of masculinity' with the rise of Christianity - in particular, Pentecostal Christianity - in 'the global South'. ${ }^{7}$ I examine Banda's sermons on 'biblical manhood' as a discursive construction of masculinity in an African Christian context. My question is how this discourse, and specifically its central notion of male headship, can be analysed and understood. Exploring this question I will review two specific bodies of scholarship. First I will look at the critical study of men, masculinities and religion, an emerging field of studies in Western academia. Second, I include the recent work of some African theological scholars on masculinities and religion. It is not only that I am aware of Western hegemony in the production of knowledge about non-Western subjects. In addition, I share these scholars' interest in how religion may contribute to a transformation of masculinities vis-à-vis some major social

4 R. R. Ruether, Sexism and God-Talk: Towards a Feminist Theology, Boston: Beacon Press 1983, 94 and 141.

5 R. R. Ruether, Christianity and the Making of the Modern Family, London: SCM Press 2001, 229.

6 Cf. D. Blankenhorn et al. (eds.), Does Christianity Teach Male Headship? The EqualRegard Marriage and Its Critics, Grand Rapids: William B. Eerdmans 2004.

7 P. Jenkins, The New Faces of Christianity: Believing the Bible in the Global South, Oxford: Oxford University Press 2006, 165. 
challenges in contemporary Africa, such as HIV and AIDS, poverty and gender-based violence.

In the following sections, first I will review the understanding of male headship, and the broader analysis of masculinity and religion, in the above mentioned bodies of scholarship. Then the focus will shift to the case study, drawing attention to the complexity and ambiguity of Banda's discourse on masculinity including his notion of male headship. In the next section I point out why the concept of patriarchy hinders a nuanced analysis of the type of discourse represented by Banda. I will present the concept of agency as an alternative interpretative tool. The objective of the article, then, is twofold: to provide insight in the (re)construction of masculinities on the basis of male headship in a local African Christian context, and to contribute to the reflection on how 'patriarchal' religious discourse on masculinity is analysed and understood in the study of religion and gender.

\section{The Critical Study of Men, Masculinities and Religion}

Surveying the field of gender studies in religion in 1995, Ursula King critically observed that she has 'yet to find a critical examination of the influence of religion on masculine gender construction. ${ }^{8}$ She underlined the need to broaden the study of religion and gender and to investigate not only the construction of femininity but also that of masculinity in specific religious teachings. King has been promptly served, as the 1990s have shown the emergence of the study of men, masculinities and religion. In 1990, the Men's Studies in Religion Group (MSRG) was established within the American Academy of Religion, and in 1996 this group published two volumes. ${ }^{9}$ From the beginning this emerging field of studies has been located in the tradition of (pro-)feminist scholarship. According to Stephen Boyd, the MSRG initiators and participants believed that:

Without a thorough and succinct investigation of masculinities and masculine experiences in all their complexity under patriarchy and a study of alternatives to patriarchy (....), the effort of feminist/mujerista/womanist scholars of religion would remain only partially successful in bringing forth a

8 U. King, 'Introduction: Gender and the Study of Religion', 5 and 12.

9 S. B. Boyd, W. M. Longwood and M. W. Muesse (eds.), Redeeming Men: Religion and Masculinities, Louisville, Kentucky: Westminster John Knox Press 1996; B. Krondorfer (ed.), Men's Bodies, Men's Gods. Male Identities in a (Post-) Christian Culture, New York and London: New York University Press 1996. 
sophisticated model of the construction of gender and in understanding its impact on religion. ${ }^{10}$

In the words of another prominent scholar in the field, Garth Kasimu BakerFletcher, the discipline of men's studies in religion is concerned with 'one central and fundamental problematic', to wit 'the historical project of patriarchy. ${ }^{11}$ Recently, Björn Krondorfer, in the introduction to his reader Men and Masculinities in Christianity and Judaism, has proposed to call the new field 'critical men's studies in religion'. By adding the term 'critical' he wishes to emphasize that 'bringing gender consciousness to the analysis and interpretation of men in relation to all aspects of religion is indispensable; otherwise, we might just slip back into a long tradition of reiterations of male dominance within the sphere of religion. ${ }^{12}$

The implications of the critical, feminist-informed edge of the study of men, masculinities and religion are clearly demonstrated in the discussion of the idea of male headship by scholars in the field. For example, in his prescriptive ethical-theological account on AfricanAmerican men, Baker-Fletcher says that the popular notion of male headship in the family and society is based on a 'sexist biblical hermeneutics', and he states that 'we must believe that God can provide us with a vision bigger than patriarchal reimpositions of "male headship".,13 More recently, Joseph Gelfer in his analysis of evangelical and Catholic masculinity in two so-called fatherhood ministries in the USA, has critically observed that male headship is a major theme proliferating through these ministries. ${ }^{14}$ He criticizes some nuanced interpretations from sociological scholars who understand the discourse on male headship in Christian men's groups in terms of 'soft patriarchy'. ${ }^{15}$ According to Gelfer, any discourse on Christian manhood and fatherhood that repeats the call to male headship must be considered with suspicion. Stating that 'the rather

10 S. B. Boyd, 'Trajectories in Men's Studies in Religion: Theories, Methodologies, and Issues' in Journal of Men's Studies 7:2 (1999), 266.

${ }^{11}$ G. K. Baker-Fletcher, 'Critical Theory, Deconstruction and Liberation?' in Journal of Men's Studies 7:2 (1999), 277.

12 B. Krondorfer, 'Introduction' in B. Krondorfer (ed.), Men and Masculinities in Christianity and Judaism: A Critical Reader, London: SCM Press 2009, xvii.

${ }^{13}$ G. K. Baker-Fletcher, Xodus: An African American Male Journey, Minneapolis: Fortress Press 1995, 38, 193.

14 J. Gelfer, 'Evangelical and Catholic Masculinities in Two Fatherhood Ministries' in Feminist Theology 19:1 (2010), 36-53.

${ }^{15}$ Gelfer specifically refers to W. B. Wilcox, Soft Patriarchy, New Men: How Christianity Shapes Fathers and Husbands, Chicago: University of Chicago Press 2004. 
unsavory cost of soft, symbolic or some other sanitized patriarchy' cannot be accepted, he underscores the need for a critical examination of religious discourses on masculinity. ${ }^{16}$ Gelfer does not further elaborate on the 'unsavoury costs', but undoubtedly he is concerned about the risk of legitimizing male dominance and about men continuing to 'hold the seat of power in the home'. ${ }^{17}$

In line with other scholars of men's studies in religion, Gelfer and Baker-Fletcher understand the theoretical and hermeneutical foundation of their work as pro-feminist and (thus) anti-patriarchal. ${ }^{18}$ Subsequently they analyse religious-cultural notions of male headship in a conceptual framework of patriarchy, with patriarchy being understood in terms of a social and symbolic structure of male dominance and the oppression of women. Moreover, they do not only offer a critical examination of male headship but also take a political stance when they explicitly oppose and reject this notion.

\section{African Theological Scholarship on Masculinities}

Compared to Western academia, in Africa it is even more a recent development that men and masculinities in religion have become a focus of academic study. African scholarship in religion and theology has a strong feminist tradition, known as African women's theology and represented by the Circle of Concerned African Women Theologians. ${ }^{19}$ In recent years this organization of African women in theological, biblical and religious studies has committed itself to the study of the intersections of gender, religion and HIV and AIDS. This was informed by the realization that HIV in subSaharan Africa is a gendered epidemic that puts women at the centre of the storm. In the words of Musa Dube:

The problem is that gender disempowers half of humanity - women. ... This serious discrepancy in the distribution of power is our unmaking in the HIV/AIDS era. It is the fertile soil upon which the virus thrives. Women who

${ }^{16}$ Gelfer, Evangelical and Catholic Masculinities in Two Fatherhood Ministries, 40.

17 Ibid., 51.

18 Baker-Fletcher, Critical Theory, Deconstruction and Liberation?, 277 and 279; J. Gelfer, Numen, Old Men. Contemporary Masculine Spiritualities and the Problem of Patriarchy, London: Equinox 2009, 11 and 15.

${ }^{19}$ Cf. M. A. Oduyoye, Introducing African Women's Theology, Cleveland: The Pilgrim Press 2001. 
have been constructed as powerless, cannot insist on safer sex. They can hardly abstain, nor does faithfulness to their partners help. ${ }^{20}$

According to African women theologians, the HIV epidemic demonstrates the urgency to transform gender relations towards gender equality or gender justice. $^{21}$ Initially embarking on the empowerment of women, these scholars have come to realize that it needs women and men to transform gender relations. Together with some male colleagues they have therefore begun to critically examine patriarchal constructions of masculinity, and they envision alternative models of masculinity. ${ }^{22}$ As part of this academicactivist scholarship, the notion of male headship is often critically mentioned. Already in 1979, Mercy Oduyoye referred to this idea as one of the most critical issues for a Christian feminist theology in Africa because of its intrinsic associations with power. ${ }^{23}$ This idea was found echoing in recent publications. Madipoane Masenya draws a direct link between the view of male headship and women's increased risk of HIV: 'The view that the headship of men is God-ordained assigns all authority and power to control to men. This includes the control of women's bodies. ${ }^{24}$ Similarly, Fulata Moyo argues that male headship functions as a justification of domestic violence and keeps women locked up in a marriage with an abusive and adulterous husband. ${ }^{25}$ African women theologians are very critical of Christian churches who, in the words of Oduyoye, 'continue to

${ }^{20}$ M. W. Dube, 'Culture, Gender and HIV/AIDS. Understanding and Acting on the Issues' in M. W. Dube (ed.), HIV/AIDS and the Curriculum. Methods of Integrating HIV/AIDS in Theological Programmes, Geneva: WCC Publications 2003, 88.

${ }^{21}$ I. A. Phiri, 'Life in Fullness: Gender Justice. A Perspective from Africa' in Journal of Constructive Theology 8:2 (2002), 69-81.

${ }^{22}$ For an overview of this development, see A. S. van Klinken, 'Transforming Masculinities towards Gender Justice in an Era of HIV and AIDS: Plotting the Pathways' in B. Haddad (ed.), Religion and HIV and AIDS: Charting the Terrain, Scottsville: University of KwaZulu-Natal Press 2011, 275-296.

${ }^{23}$ M. A. Oduyoye, 'The Roots of African Christian Feminism' in J. S. Pobee and C. F. Hallencreutz (eds.), Variations in Christian Theology in Africa, Nairobi: Uzima Press 1979, 42.

24 M. Masenya, 'Trapped between Two "Canons": African-South African Christian Women in the HIV/AIDS Era' in I. A. Phiri, B. Haddad and M. Masenya (eds.), African Women, HIV/AIDS and Faith Communities, Pietermaritzburg: Cluster Publications 2003, 119.

${ }^{25}$ F. L. Moyo, 'Sex, Gender, Power and HIV/AIDS in Malawi: Threats and Challenges to Women being Church' in I. A. Phiri and S. Nadar (eds.), On being Church: African Women's Voices and Visions, Geneva: WCC Publications 2005, 133. See also Sarojini Nadar, 'Palatable Patriarchy and Violence Against Wo/men in South Africa' in Scriptura 102 (2009), 554-555. 
use the Hebrew Scriptures and the Epistles of St. Paul to reinforce the norms of traditional religion and culture. ${ }^{26}$

One of the African male scholars in religion and theology who have done groundbreaking work on masculinities is Ezra Chitando. He has presented a case study on the Pentecostal movement in Zimbabwe, evaluating its contribution to a transformation of masculinities. In his opinion, Pentecostalism makes a meaningful contribution by shaping 'soft masculinities', that is, concepts of manhood defined by values such as sexual abstinence, marital faithfulness, family involvement. However, although Chitando considers the Pentecostal engagement with men and masculinities as promising and helpful, he is critical as well: 'The Pentecostal approach is still rooted in the paradigm of the male as the leader. ... While Pentecostals encourage women to be economically empowered, they are not willing to challenge the myth of male headship. ${ }^{27}$ According to Chitando, a more radical approach is required to transform dominant forms of masculinity: not only men's behaviour, but structures of gender need to be transformed. He considers the notion of male headship as part of indigenous and biblical patriarchies that maintain a structure of male dominance and female subordination, while in his opinion there is need for forms of masculinity that promote equality in gender relations. In an article co-authored with Sophie Chirongoma, Chitando challenges men to willingly forgo 'the patriarchal dividend' and he emphasizes the need for 'transformed, liberated and redemptive masculinities' that respect the full and equal dignity of women. ${ }^{28}$ Clearly, from his perspective cultural or religious notions of male headship are only an obstacle to achieve the transformation of masculinities that is essential for overcoming concrete social challenges such as HIV and violence against women.

The African scholars discussed in this section correspond with those who in Western academia are engaged in the study of men, masculinities and religion. In both bodies of scholarship, religious constructions of masculinity are analysed within a frame of patriarchy. Patriarchy tends to be conceptualized in a rather monolithic way, as a system of male dominance and female subordination. Moreover, scholars in both fields do

${ }^{26}$ M. A. Oduyoye, Daughters of Anowa: African Women and Patriarchy, Maryknoll: Orbis Books 1995, 174.

27 E. Chitando, 'A New Man for a New Era? Zimbabwean Pentecostalism, Masculinities and the HIV Epidemic' in Missionalia 35:3 (2007), 122 and 124.

${ }^{28}$ See E. Chitando and S. Chirongoma, 'Challenging Masculinities: Religious Studies, Men and HIV in Africa' in Journal of Constructive Theology 14/1 (2008), 66-67. 
not only demonstrate suspicion towards patriarchal religious thought but explicitly take a (pro-)feminist political stance against this thought. Consequently, they consider the notion of male headship as a patriarchal symbol that reinforces male dominance, and they tend to criticize and oppose any religious discourse on masculinity that speaks of male headship. Pointing to concrete social issues such as HIV and gender-based violence, the African scholars present us with an illustration of the argument made by their colleagues in the West: that male headship, in the words of Gelfer, has unsavoury costs.

\section{A Case Study in a Zambian Pentecostal Church}

A few years ago, bishop Joshua Banda, a well-known Pentecostal pastor in Zambia, preached a series of sermons entitled Fatherhood in the $21^{\text {st }}$ Century. The sermons were delivered in his church, Northmead Assemblies of God, which is a prominent Pentecostal church in Lusaka, the capital city of Zambia. They were also broadcasted on the national TV through the church's television programme. The sermons present a highly interesting discourse on masculinity in an African Christian context. ${ }^{29}$

The first sermon in the series was preached at Father's Day 2008. Banda seized this celebration day as an opportunity 'to discuss afresh from a biblical angle what fatherhood really means in our society. ${ }^{30}$ This is needed, he explains, because of the 'distortion of manhood', the 'violation of God's order' and the 'abdication of leadership' he observes among men in society. ${ }^{31}$ These phrases show that Banda is not simply concerned with men's role as fathers in the family, as the title of the series might suggest. Even though the title refers to fatherhood, the real topic is the broader theme of manhood. The idea of preaching on this issue was inspired by Banda's concern about men's behaviour and the popular notions of manhood underlying it. His overall concern is men's irresponsibility, and in the sermons he illustrates this with many concrete examples, such as alcoholism, sex outside marriage, absence from the family, domestic and sexual violence against women, domination over women, and the failing

29 This section draws on an analysis of six sermons. Additionally, I have made use of some of the interviews that I conducted during fieldwork periods in 2008 and 2009. The full case study can be found in A.S. van Klinken, "The Need for Circumcised Men": The Quest for Transformed Masculinities in African Christianity in the Context of the HIV Epidemic (PhD Thesis Utrecht University, 2011), 131-179.

30 FTC-1. In the footnotes, FTC refers to the Fatherhood in the $21^{\text {st }}$ Century series, while the number indicates the particular sermon in the series.

31 FTC-2. 
political and social leadership. He relates these issues to some major socioeconomic challenges in contemporary Zambia, such as the HIV epidemic, the high numbers of street kids and the high poverty levels. These realities have urged him to analyse and reflect critically on what he calls 'the male factor in society'. Through the sermons he wanted to address men's irresponsibility in various areas of life, and he wanted to teach men a constructive ideal of manhood. As he explained in an interview:

The aim in the series was to handle this [problem] from the spiritual side, because I was feeling that these men have to be addressed by a higher power. Maybe when they understand that this responsibility is given to them by God, they begin to see that when they lay back they are actually sinning against God. So that they get to see: 'Look, we have been given a divine role, let me get up and do it. ${ }^{32}$

Addressing men 'from the spiritual side' and teaching them on their 'divine role', in the sermons Banda explores a vision of 'biblical manhood'. A defining notion of Banda's ideal of 'biblical manhood' is male headship. A systematic analysis of the references to male headship makes clear that it is a complex notion which builds a rather ambiguous ideal of manhood.

First, the notion is employed to make a strong moral and spiritual appeal to men. An example of this can be found in the second sermon, where Banda re-reads the biblical story about Adam and Eve in Paradise (Genesis 3). Many feminist scholars have criticized popular interpretations of this story for blaming the Fall on Eve in emphasizing her role as the originator of sin. Interestingly, Banda presents a different reading (though I am not sure whether feminists would be less critical of his interpretation). He emphasizes that Adam, and not Eve, had received the instructions from God to keep the garden, including the prohibition to eat from the tree of knowledge of good and evil. For that reason God called for Adam rather than for Eve after the Fall. According to Banda, God's question 'Adam, where are you?' demonstrates that man has received a primary responsibility from God. However, man failed to take his responsibility when he allowed the devil to come into the garden and trick Eve. ${ }^{33}$ Banda directly applies this story to the men to whom he is preaching when he is saying: 'When God is going to correct the situation in Eden, he first goes to the man: "Adam, where are you?" So as society is where it is now, the first

32 Interview with Joshua H. K. Banda, Lusaka: 5 November 2008.

33 This reading of Genesis 2-3 is not uncommon in Pentecostal circles in Africa. E.g. J. Soothill, Gender, Social Change and Spiritual Power: Charismatic Christianity in Ghana, Leiden: Brill 2007, 186-187. 
question we must ask is: "Where is the man?"'34 Repeating this question several times, Banda makes clear that Adam is not the only one who failed to take his responsibility, since he is paradigmatic of men in general. In this context, reference is made to male headship:

We men are the head, but you have to live up to it. We like to be the head, but we don't like to live up to the responsibility. That's our problem! All over the world men are in the majority of leadership positions, but look at the level of oppression. We are doing a very bad job.... Shame on us, men. Why? Because of our abdication. God is seeking to correct that. He says to the man: 'Where are you?' Today I ask you: 'Men, where are you?' In God's economy, question number one is: 'Man, where are you?' We don't give answer to that question, because we have abdicated our role. ${ }^{35}$

This quotation demonstrates that Banda does not question the notion of headship - he rather takes it for granted - but that he radically relates it to the ethical demand of taking responsibility. Later on I will explore this call for responsibility, but here I draw attention to its rhetorical dependence on the notion of male headship: precisely because men are considered to be the head, they are called to live up to the implied responsibilities. The link between male headship and the ethical-spiritual call on men is not only a rhetorical but also a theological one. It is said that men have been given the role of head. According to Banda, men have received this role when God gave the instructions for life to Adam. Also the 'fact' that Adam was created first is understood as an indication of 'the principle of male headship'. ${ }^{36}$ This principle is believed to be fundamental to God's order of creation. Evidently, this theological view adds further weight to the call for men to live up to the responsibilities that are related to their divine role.

Second, the idea of male headship is clearly distinguished from male domination and is even used to criticize dominating, oppressive and violent performances of manhood. In one of the sermons Banda states explicitly: 'Male headship does not mean male domination. What we have seen most times is male domination. And it stinks in the nostrils of God. It is a distortion of God's order. Because male domination implies that the woman is less than the man, but that's not biblical. ${ }^{37}$ For the church leadership it is a major concern that men tend to understand male headship in terms of superiority over women. According to a church-based

\footnotetext{
34 FTC-2.

${ }^{35}$ FTC-2.

${ }^{36}$ FTC-6.

37 FTC-6.
} 
marital counsellor, men's misunderstanding of male headship and their subsequent 'dictatorial behaviour' to their wives are at the root of most problems in marriages. She concretely relates this to the issue of decisionmaking in marriage:

Generally men understand that because they are the head they have to make all the decisions. Yes they have to give the direction, but how that is done is what usually brings problems in marriages. And generally women will find that there are many times that a man has made decisions without consulting the wife. They are just expected to submit to his decision. And I think it is all, again, a wrong interpretation of what headship means and what submission is. ${ }^{38}$

Concerns like this have inspired Banda to the Fatherhood in the 21st Century series. He argues extensively that male headship entails 'a primary responsibility to lead the partnership in a God-glorifying direction', but that this leadership 'is to serve rather than to dictate' and 'is to mobilize the strength' of all family members including the wife. ${ }^{39}$ Jesus is presented as an example of this servant leadership. ${ }^{40}$ Ephesians 5:25, where the relation of the husband to the wife is presented in analogy to the relation of Christ to the church, is used to qualify male headship christologically in terms of self-giving love. On this basis Banda addresses men in the audience, saying: 'We can't just go around and say: we are the primary head, and in the meantime we are pressing everybody around. We must do it in accordance to the prescription in Scripture. ${ }^{41}$ This emphasis on the 'biblical' meaning of male headship is worth mentioning because Banda compares this to the 'traditional' or 'African' understanding. In his opinion, the tendency of men to dominate women and to exercise power in an oppressive way is part of African culture, while the Christian version of male headship respects women's dignity and acknowledges women's capacities. Similar views are reflected by other church leaders and members. This corresponds with the observation of Jane Soothill from her research in Pentecostal churches in Ghana:

\footnotetext{
${ }^{38}$ Interview with NAOG marital counselor, 29 October 2008.

39 FTC-3.

${ }^{40}$ Specific reference is made to Jesus washing the feet of his disciples and to Luke 22:26 which reads (NIV): 'The greatest among you should be like the youngest, and the one who rules like the one who serves.' Applying this to men Banda says that 'a man should not demand to be served; rather he possesses the strength to serve and to sacrifice.' (FTC-4).

41 FTC-6.
} 
[M]ale headship does not mean that men are superior to women, or more precisely that the husband is superior to the wife. The concept of superiority of the man over the woman is presented as an African traditional belief. .... [D]efinitions of male headship within born-again Christianity tend to be contrasted with what are perceived to be "traditional African values" about men and their masculine identities. ... In born-again Christianity, then, the concept of male headship is redefined in terms of "love" and "sacrifice". 42

It is noteworthy that Banda does not only clearly distinguish between male headship and male domination, rejecting the latter, but also carefully links male headship to a notion of gender equality. One long sermon is entirely devoted to 'reconciling' and 'balancing' male headship with the idea of male and female equality. For Banda, both notions are biblical and part of God's order. Drawing from Genesis 1:27 he argues that man and woman equally bear the image of God. This means, in his opinion, that men and women are 'equal in personhood', have 'equal access to the grace of life' and are both 'supposed to express God's holiness'. ${ }^{43}$ This provides him with a theological basis to condemn issues such as violence against women. For a man to batter his wife, or even to look down on women, is 'an insult to God' because women are created in God's image. ${ }^{44}$ Drawing from Genesis 1:26 Banda also highlights that humankind as a whole has received the command to rule over the earth. It forms his basis for arguing that both men and women have to play a role in society. He can even imagine that a woman is president of the nation or is heading a company, and emphasizes that men should respect women in such leadership positions. It appears that Banda invokes the notion of equality to allow for women's participation in society, the economy and the church. In correspondence with this, he applies male headship strictly to the marital and family setting, dissociating it from the connotation of dominance and thus redefining its meaning.

Third, an alternative understanding of headship as 'taking responsibility' is presented. Raising the question of what male headship shoud actually imply, Banda quotes the American evangelical theologian Raymond Ortlund saying: 'In the partnership of two spiritually equal human beings, man and woman, the man bears the primary responsibility to lead

\footnotetext{
42 Soothill, Gender, Social Change and Spiritual Power, 191, 192, 193.

${ }^{43}$ FTC-6.

44 FTC-6.
} 
the partnership in a God-glorifying direction. ${ }^{45}$ In an earlier sermon, Banda had cited another American evangelical author, John Piper, to define 'biblical manhood': 'At the heart of mature masculinity is a sense of benevolent responsibility to lead, provide for and protect women in ways appropriate to a man's differing relationships. ${ }^{46}$ Ortlund and Piper provide a conservative response to 'evangelical feminism'. Although Banda makes use of their writings, he has a different agenda. Indeed, he also argues that feminist movements have been wrong to fight male headship, and says feminists should accept the biblical order. However, when preaching on headship Banda primarily addresses men, reminding them of their 'Godgiven responsibilities'. He applies the notion of responsibility more specifically to particular areas of men's lives, varying from sexuality, the marital relationship and family life to society at large.

With regard to sexuality, in one of the sermons Banda narrates how he, when his son turned fifteen, called him and his friends together to tell them that 'manhood is not about your sexuality, but about responsibility, courage and commitment.' Directly after that, referring to the high prevalence of HIV in Zambia, he says that 'Adam, prior to the fall, was placed at a location where he had to be responsible, but he failed and that's why we are where we are now. ${ }^{47}$ In the context of marriage and the family, a man's position as head of the home means, according to Banda, that he has to provide in the material and spiritual needs of his wife and family. With regard to the material needs, he underlines that men have a primary responsibility but that women can also contribute to the income of the household. Acknowledging that in many cases women are actually making a substantial contribution to the household income, Banda puts emphasis on men's responsibility to provide for the spiritual needs of the family. Furthermore he reminds them of their task to mobilize the capacities of their wife and to 'create an atmosphere where initiatives can thrive'. ${ }^{48}$ In a subtle way, the traditional understanding of men as breadwinners is redefined and adapted to the modern realities of urban

${ }^{45}$ R. C. Ortlund, 'Male-Female Equality and Male Headship: Genesis 1-3' in J. Piper and W. Grudem (eds.), Recovering Biblical Manhood and Womanhood: A Response to Evangelical Feminism, Wheaton: Crossway 1991, 95, quoted by Banda in FTC-6.

46 J. Piper, 'A Vision of Biblical Complementarity: Manhood and Womanhood Defined According to the Bible' in J. Piper and W. Grudem (eds.), Recovering Biblical Manhood and Womanhood: A Response to Evangelical Feminism, Wheaton: Crossway 1991, 35, quoted by Banda in FTC-3.

47 FTC-3.

48 FTC-5. 
middle-class families, while upholding the 'biblical principle' of male headship. At the level of society in general, Banda understands men's responsibility in terms of leadership. Referring to the mess in which we are', in Zambia and worldwide, because of men's oppressive and selfcentred leadership style, he calls on men to use their power constructively and for the benefit of others. Men have to model their leadership after Christ, who is considered an example par excellence of a man who took his responsibility, was committed to humanity and showed servant leadership. According to Banda, Jesus Christ is the second Adam, who finally has answered God's question of 'Adam, where are you?', restoring the ideal of manhood and liberating men from bondages of the past so that they can become born-again as men. ${ }^{49}$

Banda's interpretation of male headship in the Fatherhood in the $21^{\text {st }}$ Century sermons confirms the thesis that Pentecostal Christianity in Africa wants individuals, in the words of Birgit Meyer, 'to make a complete break with the past. ${ }^{50}$ Male headship is dissociated from the supposed traditional cultural connotation of dominance, and is re-framed in a "modern" global Pentecostal discourse of responsibility and servant leadership. The references to Ortlund and Piper as well as the similarities between Banda's ideal of 'biblical manhood' and movements such as the Promise Keepers ${ }^{51}$, show that this discourse stems primarily from NorthAmerican evangelical Christianity. It is important, however, to observe how this global discourse is translated to the local context in view of major social issues in urban Zambia like HIV and AIDS, changing gender and family relations, gender-based violence and poverty. As a response to the poor socio-economic situation of Zambia, Banda uses the notion of male headship to mobilize men to behavioural change, to address popular perceptions of manhood in society and to contribute to a transformation of masculinities by promoting 'biblical manhood'.

49 FTC-5.

50 B. Meyer, "Make a Complete Break with the Past": Memory and Post-Colonial Modernity in Ghanaian Pentecostalist Discourse' in Journal of Religion in Africa 28:3 (1998), 316-349.

51 Cf. R. H. Williams (ed.), Promise Keepers and the New Masculinity: Private Lives and Public Morality, Lanham: Lexington 2001; D. S. Claussen (ed.), The Promise Keepers: Essays on Masculinity and Christianity, Jefferson: McFarland 2000. 


\section{Male Headship and the Framework of Patriarchy}

The sermons in Fatherhood in the $21^{\text {st }}$ Century demonstrate some of the complexities of Pentecostal discourse on gender. Traditional ('biblical') notions of gender are maintained while their meaning is re-interpreted. At the same time, modern (Western) notions of gender are being introduced and to some extent incorporated. ${ }^{52}$ In this way Pentecostalism can have 'a modernizing egalitarian impulse' while upholding patriarchal notions such as male headship in marriage..$^{53}$ It can be considered part of what Bernice Martin calls the Pentecostal gender paradox that the notion of headship in Banda's sermons functions as a biblical-theological basis to address hegemonic forms of masculinity and to define a more constructive ideal of manhood. Feminist and gender-critical scholars have shown little awareness of this ambiguity. As Elizabeth Brusco comments, the contribution of Pentecostalism to 'a transformation of the male role (including getting men to be less abusive, contribute to child care, and remain faithful in a relationship) has been the hardest challenge facing Western feminists. ${ }^{54}$ This observation does not only apply to Western feminists but also to scholars of men, masculinities and religion, both in the Western world and in Africa. Ezra Chitando's paper on 'the new man' in the Zimbabwean Pentecostal movement is exemplary here. Although Chitando applauds the success of Pentecostalism in transforming masculinities, he remains critical of the fact that the Pentecostal approach 'is rooted in the paradigm of the male as the leader' and does not challenge 'the myth of male headship'. ${ }^{55}$ Apparently Chitando does not realize that the Pentecostal efforts to bring about change in men and masculinities rest on the very pillars of male leadership and headship. The relative success of these efforts are likely to be explained from the transformative power of these notions in the frame of Pentecostal spirituality and theology. The analytical blind spot about the complex meaning and the potentially transformative impact of discourses on male headship in local contexts can be explained from the limitations of the conceptual framework of

52 See E. Brusco, 'Gender and Power' in A. Anderson et al. (eds.), Studying Global Pentecostalism: Theories and Methods, Berkeley etc.: University of California Press 2010, 74-92; B. Martin, 'The Pentecostal Gender Paradox: A Cautionary Tale for the Sociology of Religion' in R. K. Fenn (ed.), The Blackwell Companion to the Sociology of Religion, Oxford: Blackwell 2001, 52-66.

53 Martin, 'The Pentecostal Gender Paradox', 54.

54 Brusco, 'Gender and Power', 80.

${ }^{55}$ Chitando, 'A New Man for a New Era?', 122 and 124. 
patriarchy that dominates the current study of religion and masculinities. These limitations are related to the following factors.

Firstly, both masculinities and religion are often analysed by means of a rather monolithic concept of patriarchy. The concept posits a fixed structural inequality between men and women, and it tends towards a dichotomous understanding of gender in terms of female submission and male domination. This view of patriarchy, which is in line with early feminist theory, has been increasingly subjected to criticism in more recent theories of gender. ${ }^{56}$ They draw attention to the complexity of gender relationships and to the fluidity and ambiguity of gender identities. Moreover, these theories point to the subjectivity and agency of individuals within powered gender structures. Applying this criticism to the study of men and masculinities, Stephen Whitehead has stated that in the framework of patriarchy, 'all that is seen is the structure'. ${ }^{57}$ According to Whitehead, the focus tends to be on a fixed structure of male power, while the diversity among men, the complexity and ambiguity of masculinities, and the subjectivity and agency of individual men, are hardly taken into account. As a consequence, in this frame male headship can only be considered a symbol of male dominance that reinforces gender inequality. Additionally, the power attached to men, either socially or symbolically, is already suspect in advance. '[I]n foregrounding the analytical term "patriarchy", we misleadingly assume that we already know what power means,' says the anthropologist Mayba Mayblin: power is equated with domination. From her research on gender relations in a Catholic Brazilian context Mayblin says that even when a patriarchal social organization is a "fact", the challenge is 'to explore what power actually means in terms of the roles people occupy. ${ }^{58}$ I would not only apply this to the social organization of gender but also to the symbolic and ideological levels where gender is interpreted, such as in religious discourse. What kind of power is assigned to men, and how is it framed? As outlined above, Banda

56 Already in 1990 Judith Butler referred to patriarchy as a reified construct within feminism as it 'has threatened to become a universalizing concept that overrides or reduces distinct articulations of gender asymmetry in different cultural contexts. ... The articulation of the law of patriarchy as a repressive and regulatory structure requires reconsideration from this critical perspective.' See J. Butler, Gender Trouble: Feminism and the Subversion of Identity, London: Routledge $2006^{2}$ [1990], 48.

57 S. M. Whitehead, Men and Masculinities: Key Themes and New Directions, Cambridge: Polity Press 2002, 93, but see 86-94.

58 B. Mayblin, Gender, Catholicism and Morality in Brazil: Virtuous Husbands, Powerful Wives, New York: Palgrave MacMillan 2010, 13. 
clearly dissociates male headship from oppressive forms of power and seeks to promote a constructive exercise of power. He frames this in a Christological model of servant leadership.

Secondly, the framework of patriarchy is particularly limited when is it applied to the analysis of men and masculinities in relation to religion. It is true that the concept of patriarchy points to a fundamental insight concerning the extent of male dominance in religious traditions. However, the concept is not sensitive to the differences between, and nuances within, patriarchal religious discourses. Neither does it display much sensitivity to the complexity and ambiguity of ideals of masculinity in religious traditions. In the frame of patriarchy, such ideals are likely to be considered as fitting in and reinforcing a structure of male dominance. It is not taken into account that they may also subvert or contest patterns of male dominance. Furthermore, it is overlooked that the meaning of these ideals and the notions underlying them are never self-evident. With Ursula King and Carolyn Walker Bynum, I consider Victor Turner's thesis of the polysemic nature of religious symbols as particularly relevant to the understanding of symbols and discourses concerning gender: their meaning is never fixed or self-evident but, instead, multiple, fluid and ambiguous. ${ }^{59}$ As Bynum puts it, 'gender-related symbols, in their full complexity, may refer to gender in ways that affirm or reverse it, support or question it. ${ }^{60}$ Applied to the symbol of male headship, which is part of a central theological imaginary about the relation of Christ to the Church, it is evident that it does not simply confirm a single structure of male dominance. Banda's sermons show how male headship can be used to challenge men's oppression of women. Moreover, 'balancing' and 'reconciling' male headship with a notion of male-female equality the sermons illustrate the ambiguity of gender in the sphere of religion.

Third, patriarchy is a highly politicized concept: it refers to the reality and ideology that feminist politics seeks to criticize and overcome. Scholars who take this concept as their major analytical frame will not only critically analyse religious thought, practices and symbols related to masculinity. Also they evaluate and reject notions, practices and symbols that in their opinion are patriarchal, and advocate alternative concepts of masculinity. Both the Western study of men, masculinities and religion and

\footnotetext{
59 U. King, 'Introduction: Gender and the Study of Religion', 4; C. W. Bynum, 'Introduction: The Complexity of Symbols' in C. W. Bynum, S. Harrell and P. Richman (eds.), Gender and Religion: On the Complexity of Symbols, Boston: Beacon Press 1986, 2.

60 Bynum, Introduction: The Complexity of Symbols, 2
} 
African theological scholarship on masculinities are exemplary here. I agree with the cultural anthropologist and feminist theorist Saba Mahmood that the political prescriptive project of feminism, characterized by a commitment to a single (Western) ideal of gender equality, can become an obstacle to an analysis of gender in all its complexities in concrete sociocultural contexts. ${ }^{61}$ Without going to the extreme of 'objective' and 'neutral' scholarship, I think the primary task of scholarship in religion and gender is to critically analyse in a detailed and nuanced way the complex processes in which gender is (re)produced in religious contexts. As a European researcher working in cross-cultural contexts within contemporary world Christianity, I feel it is problematic to take a normative stance against the beliefs of a particular Christian community, say in Africa. Rather, my interest is in how gender is constantly (re)produced in specific Christian contexts vis-à-vis changing socio-cultural realities. From this perspective it is fascinating to see how a Zambian Pentecostal pastor employs the 'patriarchal' notion of male headship to bring about a transformation of masculinities in the face of social challenges such as HIV and AIDS and gender-based violence.

\section{Male Headship as Male Agency}

As the concept of patriarchy is too limited to understand the meaning and function of religious discourse on male headship in local contexts, the question is what alternative analytical concept can be utilized. My suggestion is that the concept of agency will be able to bring us a step further.

A key concept in cultural anthropology, 'agency' broadly refers to the capability and power of an individual to be the source and originator of acts within certain social structures. ${ }^{62}$ Although the relation between individual agency and structures of power in society is a much debated issue, at least the concept of agency implies that social structures never fully determine and regulate people's behaviour but leave space for variation, subversion and resistance. In feminist and gender studies, agency is often used to theorize how women resist, subvert and/or negotiate patriarchal gender norms, thus going beyond simplistic views of female subordination and powerlessness. Agency has rarely been conceptualized

61 S. Mahmood, Politics of Piety: The Islamic Revival and the Feminist Subject, Princeton and Oxford: Princeton University Press 2005, 1-39.

62 N. Rapport and J. Overing, Social and Cultural Anthropology: The Key Concepts, London: Routledge 2000, 1-9. 
in relation to men as gendered beings, which is explicable from the feminist trajectory of the concept: agency is understood in terms of subversive and liberatory enactments of power by those who are 'oppressed'. In this frame, male power is simply assumed and contested rather than thought of in terms of agency. However, as the complexity and ambiguity of gender relations are increasingly acknowledged, concepts of agency are further developed as well. ${ }^{63}$ How, then, can agency be applied to men and masculinity?

Masculinity studies have coined the concept of masculinity as a plural, masculinities, as a means to overcome a dichotomous notion of gender as male dominance and female subordination. R. W. Connell has developed a theory on masculinities, distinguishing between hegemonic masculinity - the form of masculinity that is dominant in a society and that prescribes the image of a 'real man' - and other forms of masculinity that are subordinated to, complicit with, or marginalized by the hegemonic one. Connell mentions, but does not explore, that this theory presupposes a notion of personal agency. ${ }^{64}$ Individual men are confronted with multiple discourses on masculinity. The perception and performance of their male gender identity is constituted by their engagement in, resistance to, subversion of and modelling after specific discourses on masculinity. Because of this space for agency it also makes sense to intervene in the dynamics of masculinities. This is what Banda is doing in his sermons in Fatherhood in the $21^{\text {st }}$ Century: he deliberately creates a new discourse on masculinity in order to contest the hegemonic masculinity and to open up a space in which men's gender identities can be reshaped. Banda mobilizes male agency by challenging hegemonic perceptions of masculinity in society and by reminding men that they have a choice to live up to an alternative ideal. In contemporary African settings, the need to 'target men for a change' is widely acknowledged. ${ }^{65}$ Where various masculinityintervention programmes employ a discourse of gender equality and human rights, Banda uses male headship as a key notion to bring about change in men and masculinity. It is not difficult to understand why this may be effective in an African Christian context. Here, human agency is embedded in a religious frame, and change in one's self is a response to

${ }^{63}$ Cf. L. McNay, Gender and Agency: Reconfiguring the Subject in Feminist and Social Theory, Cambridge: Polity Press 2000.

${ }^{64}$ R. W. Connell, Masculinities (2 ed.), Berkeley : University of California Press 2005, 68.

${ }^{65}$ Cf. J. Bujra, 'Targeting Men for a Change: AIDS Discourse and Activism in Africa' in F. Cleaver (ed.), Masculinities Matter! Men, Gender and Development, London: Zed Books 2002, 209-234. 
God, 'the morally relevant Other demanding work by the self on the self. ${ }^{16}$ From this perspective it is important to observe that Banda presents the practice of male headship as a response to God's question to Adam: 'Adam, where are you?', and that he presents Jesus Christ - the one who actually answered God's question to Adam - as the model of 'biblical manhood'. In this way, male headship is embedded in the major theological narrative of Pentecostal Christianity, which makes it a powerful notion to enable male agency.

As a polysemic religious symbol, male headship can have different meanings and therefore give rise to different forms of agency in men. In some cases it may mean agency-as-domination. Exactly this form of male agency is addressed by Banda and redefined in terms of agency-as-takingresponsibility. This shift of meaning may not altogether dispel the gendercritical scholar's suspicion, since we can hardly think about headship without the connotation of a gender hierarchy. It remains a critical question why only men are considered to hold a divinely ordained position as heads. However, our concerns do not release us from the task to analyse religious and gendered notions in their specific context. Such an analysis shows that the meaning of male headship varies and that its implications for men and masculinities can be more constructive than the suspicious scholar may want to admit.

${ }^{66}$ F. Klaits, 'Introduction: Self, Other and God in African Christianities' in Journal of Religion in Africa 41:2 (2011), 144. 